\title{
PENDAMPINGAN MANAJEMEN WAKTU ANAK PADA MASA NORMAL BARU DI DUSUN DESEKAN KABUPATEN MAGELANG
}

\section{CHILDREN'S TIME MANAGEMENT MENTORING IN NEW NORMAL PERIOD IN DUSUN DESEKAN MAGELANG REGENCY}

\author{
Fiki Fitriyah $^{1)}$, Yeny Fitriyani ${ }^{2}{ }^{*}$, Milna Wafirah ${ }^{3)}$, Achmad Labib ${ }^{4)}$, Titis Rosowulan ${ }^{5)}$ \\ ${ }^{1)}$ Program Ekonomi Syariah STAI Al Husain. email: fikikikay287@ gmail.com \\ ${ }^{2)}$ Program Ekonomi Syariah STAI Al Husain. email: yenyfit@staia-sw.ac.id \\ ${ }^{3)}$ Program Manajemen Pendidikan Islam STAI Al Husain. email: milnawa@ staia-sw.ac.id \\ ${ }^{4)}$ Program Ekonomi Syariah Al Husain. email: alabibasrori@staia-sw.ac.id \\ ${ }^{5)}$ Program Manajemen Pendidikan Islam Al Husain. email: titisr@ staia-sw.ac.id
}

\begin{abstract}
ABSTRAK
Tatanan Hidup Baru (New Normal) dimasa pandemi COVID-19 memberikan pengalaman yang benar-benar baru bagi dunia pendidikan khususnya siswa Sekolah Dasar (SD) di Indonesia. Kewajiban untuk taat protokoler kesehatan yang salah satu klausulnya adalah tidak berkerumun dan menjauhi krumunan menjadikan kegiatan belajar mengajar sangat tidak biasa. Tidak ada tatapmuka baik dengan guru ataupun teman, semua dilakukan secara daring (online). Hal tersebut membuat pelajar mempunyai waktu luang yang banyak dan cenderung tanpa pengawasan baik dari orang tua maupun guru. Tujuan pengabdian ini adalah untuk mengoptimalkan waktu luang siswa dengan manajemen waktu di masa normal baru. Metode yang digunakan dalam penelitian ini menggunakan metode Participatory Action Research (PAR). Tahapan penting dalam PAR adalah Research (pemetaan masalah), Action (rencana aksi dalam penyelesaian masalah) and Participatory (orang tua dan siswa SD di Desa Desekan). Teknik Pengumpulan data dilakukan dengan observasi, survei, dokumen dan wawancara. Pendampingan diharapakan dapat membantu siswa memahami pentingnya manajemen waktu dengan membuat jadwal kegiatan harian sehingga siswa dapat memanage waktunya dengan efektif dan efisien. Kesimpulan dari pengabdian ini adalah para siswa belum memahami dengan baik mengenai manajemen waktu dan banyak menghabiskan waktu dengan dawai dan bermain yang tidak berhubungan dengan pendidikan.
\end{abstract}

Kata kunci: Tatanan Hidup Baru, COVID-19, Manajemen Waktu, PAR

\section{ABSTRACT}

The New Living Order (New Normal) during the COVID-19 pandemic provided a completely new experience for the world of education, especially elementary school students in Indonesia. The obligation to comply with the Health protocol makes learning without face-toface either with teachers or friends and everything is done online. This makes students have a lot of free time and tends to be without supervision from either parents or teachers. The aim of this service is to optimize students' free time with time management in the new normal. The method used in this study uses the Participatory Action Research (PAR) method. The important stages in PAR are Research (mapping problems), Action (action plans in solving problems) and Participatory (participation of parents and elementary students in Desekan village). The technique of collecting data was carried out by observation, surveys, documents and interviews. It is hoped that mentoring can help students understand the importance of time management by scheduling daily activities so that students can manage their time effectively and efficiently. The conclusion of this dedication is that the students do not understand well about time management and spend a lot of time with strings and games that are not related to education.

Keywords: New Normal, COVID-19, Time Management, PAR 


\section{PENDAHULUAN}

Pandemi COVID-19 merupakan krisis kesehatan yang pertama di Wuhan dan terutama di dunia. Mayoritas negara di dunia memutuskan untuk menutup sekolah, perguruan tinggi dan universitas. Perserikatan Bangsa-Bangsa (PBB) menjadi gusar dengan adanya fakta tersebut. Organisasi Internasional yang bermarkas di New York tersebut menangkap bahwa pendidikan menjadi salah satu sektor yang sangat terdampak oleh virus corona atau COVID-19. Hal tersebut diperparah dengan persebaran yang tergolong masif dan skala yang luas. Berdasarkan laporan ABC News 7 Maret 2020, penutupan sekolah terjadi di lebih dari puluhan negara karena wabah COVID-19. Menurut data Organisasi Pendidikan, Keilmuan, dan Kebudayaan PBB (UNESCO), setidaknya ada 290,5 juta siswa di seluruh dunia yang aktivitas belajarnya menjadi terganggu akibat dari penutupan sekolah tersebut [1].

Indonesia menjadi salah satu dari 74 negara yang meliburkan seluruh aktivitas belajar secara langsung (tatap muka) di semua tingkatan Pendidikan. Hal ini membuat pemerintah harus bertindak dengan cepat dengan menghadirkan alternatif proses pendidikan bagi peserta didik dalam bentuk platform pembelajaran dan perangkat lain seperti pembelajaran jarak jauh yaitu dalam jaringan (daring) dan luar jaringan (luring). Daring dalam Kamus Besar Bahasa Indonesia diartikan dalam jaringan, dimana terhubung melalui jaringan komputer, internet dan sebagainya [2]. Sedangkan sistem luring (luar jaringan) adalah pembelajaran dengan menggunakan papan tulis dan buku pegangan siswa atau guru ditambah dengan penggunaan laptop dan proyektor dengan materi yang diketik di pengolah kata [3].

Semenjak sekolah memakai sistem daring dan luring, anak-anak cenderung lebih banyak santai dengan main gawainya dibandingkan dengan belajarnya. Berbeda halnya jika anak-anak sekolah, dimana siswa harus memperhatikan guru saat pembelajaran berlangsung. Orang tua yang bekerja dan tidak memiliki tingkat pengetahuan yang cukup juga menjadi kendala dalam mengontrol anak-anak untuk mengikuti pelajaran. Oleh karena itu perlu adanya pendampingan manajemen waktu anak di masa normal baru ini agar jadwal belajar, istirahat, dan bermain anak-anak bisa lebih tertata dan terstruktur sehingga tidak ada waktu yang terbuang sia-sia dan tetap produktif meskipun di masa normal baru.

Manajemen waktu menurut Atkitson dalam Yuswardi, Rizal dan Fajri adalah sesuatu jenis keterampilan yang berkaitan dengan segala bentuk upaya dan tindakan seorang individu tersebut memanfaatkan waktunya dengan sebaik-baiknya. Demi tercapainya manajemen waktu yang berhasil dan berdaya guna, diperlukan pemahaman tentang prinsip dasar manajemen waktu, penjadwalan, dan pelaksanaan kegiatan yang dapat dipertanggungjawabkan dalam kehidupan sehari-hari. Apabila anak-anak 
dimasa normal baru dapat mengatur

waktunya dengan efektif dan efisien, maka jadwal mereka akan lebih tertata dan terstruktur sehingga tidak ada waktu yang terbuang sia-sia [4].

Adapun indikator manajemen waktu menurut Wati, et al adalah mengatur waktu yang teratur, menyelesaikan tugas tepat waktu, merencanakan jadwal dengan baik, dan menggunakan waktu secara efektif dan efisien (5). Sedangkan definisi Normal Baru (New Normal) menurut Junaidi adalah paradigma hidup baru, dimana manusia harus berdamai berdampingan dengan Covid-19, yaitu hidup sesuai dengan protocol kesehatan, seperti pola hidup sehat dan bersih serta menggunakan masker selama vaksin belum ditemukan. Era New Normal atau Normal baru diberlakukan oleh pemerintah dengan tujuan untuk menyelamatkan negara [6].

Dusun Dasekan adalah salah satu dusun di Desa Sumberarum Kecamatan Tempuran Kabupaten Magelang yang menjadi lokasi pengabdian yang dipilih oleh pendamping. Selain dikarenakan asal pendamping, pendamping juga melakukan observasi dengan penyebaran beberapa kuisioner dan wawancara awal yang memperlihatkan bahwa cara belajar anak-anak dimasa new normal atau normal baru tidak berjalan sebagaimana mestinya. Jam belajar anakanak SD yang sebelum pandemi terjadwal dari jam 7-12 WIB sekarang hanya beberapa menit saja dan hanya diisi dengan pemberian tugas oleh guru kemudian tugas itu dikumpulkan disekolah, selebihnya anakanak banyak yang terlihat main dan sibuk dengan gawai mereka masing-masing. Hal tersebut mengakibatkan waktu anak tidak termanage dengan baik.

Dengan mempertimbangkan latar belakang di atas maka pendamping menemukan masalah dimana perlu adanya manajemen waktu anak di masa normal baru untuk mengoptimalkan waktu anak, sehingga waktu belajar, bermain dan istirahat lebih teratur. Adapun tujuan pengabdian adalah untuk mengetahui bagaimana cara mengoptimalkan waktu anak dengan manajemen waktu di masa normal baru.

Maka dari itu karena manajemen waktu anak di masa normal baru ternyata memang sangat penting dan harus di implementasikan pendamping berinisiatif untuk memberikan judul pengabdian ini yaitu Pendampingan Manajemen Waktu Anak di Masa Normal Baru.

\section{METODE PELAKSANAAN KEGIATAN}

Jenis penelitian yang digunakan dalam penelitian ini menggunakan metode studi kasus kualitatif. Menurut Strauss dan Corbin, penelitian kualitatif adalah jenis penelitian yang menghasilkan penemuan penemuan yang tidak dapat dicapai dengan menggunakan prosedur-prosedur statistik. Penelitian kualitatif secara umum dapat digunakan untuk penelitian tentang kehidupan masyarakat, sejarah, tingkah laku dan yang lainnya [7].

Data yang digunakan diperoleh dari hasil observasi langsung di lapangan, wawancara 
dengan orang tua atau wali murid sebanyak

10 narasumber dan juga disertai dokumentasi

kegiatan. Selain itu juga didukung dengan

beberapa kuisioner yang juga disebarkan

kepada wali murid atau orang tua anak sebanyak 10 kuisioner.

Metode yang digunakan dalam penelitian ini adalah metode Participatory Action Research (PAR). Metode PAR memiliki tiga variabel kunci yaitu, Partisipatoris, Action (aksi), dan Research (penelitian). Sedangkan berdasarkan urutan metodologi kerja PAR ketiga Variabel tersebut dirumuskan sebagai berikut.

1. Research (Penelitian), tahap ini adalah merupakan tahapan penelitian tentang permasalahan-permasalahan yang dihadapi oleh masyarakat, permasalahan tersebut dipahami sedemikian mendalam dan mendetail sehingga masalah tersebut bisa diketahui dengan jelas sebab dan akibatnya.

2. Action (aksi), setelah mengetahui masalah-masalah tersebut secara mendalam dan mendetail, barulah masuk langkah yang kedua yaitu pencarian alternative jalan keluar untuk memecahkan masalah tersebut, yang kemudian diterjemahkan kedalam beberapa item program kerja yang akan dilaksanakan.

3. Participatory, kedua poin diatas dilaksanakan secara partisipatoris, artinya dengan melibatkan seluruh komponen masyarakat dalam melakukan identifikasi masalah serta teknik pemecahannya secara bersama-sama [8].

Pendamping bersama-sama masyarakat melakukan identifikasi masalah, perencanaan, dan aksi untuk menyelesaikan persoalan-persoalan yang mereka hadapi melalui ketiga prinsip tersebut. Disamping itu nuansa penelitian serta kritik yang konstruktif terhadap kondisi pendampingan tersebut menjadi tugas independent sebagai bentuk laporan pertanggungjawaban atas keterlibatan antara pendamping dan masyarakat.

Adapun subjek yang terlibat dalam pengabdian masyarakat ini adalah anak-anak di Dusun Dasekan, Desa Sumberarum, Kec. Tempuran, Kab. Magelang yang pada masa normal baru ini belajar di sekolah dan di rumah menggunakan sistem daring dan luring, wali murid atau orang tua anak, dan perangkat desa. Kegiatan pendampingan manajemen waktu anak di masa normal baru bertempat di Dusun Dasekan, Desa Sumberarum, Kec. Tempuran, Kab. Magelang dengan lama kegiatan selama 45 hari pada bulan Juli-Agustus 2020.

\section{HASIL DAN PEMBAHASAN}

Adapun hasil yang diperoleh adalah sebagai berikut.

1. Research (Penelitian)

Pada langkah awal, pendamping menganalisis masalah di Dusun Dasekan, Desa Sumberarum, Kecamatan Tempuran, Kabupaten Magelang. Pendamping menemukan bahwa di masa normal baru, anak-anak belajar dengan sistem daring dan luring. Hal tersebut membuat jadwal belajar 
anak-anak tidak tertata dan terstruktur, dimana jadwal belajar digunakan untuk bermain atau bahkan sampai tidak ada jadwal belajar. Orang tua pun merasa kesusahan dalam mendampingi belajar anak karena orang tua sibuk bekerja, sehingga waktu untuk mendampingi belajar anakanak menjadi tidak optimal.

\section{Action (Aksi)}

Setelah dilakukan analisis masalah, maka diperlukan pendampingan manajemen waktu anak agar jadwal belajar, istirahat, dan bermain dapat tertata dan terstruktur. Berdasarkan analisis masalah tersebut maka pendamping berinisiatif untuk dapat mengoptimalkan waktu anak dengan manajemen waktu dengan membuat program kerja diantaranya adalah membuat jadwal kegiatan harian, belajar bareng, dan membuat prakarya di hari weekend.

Cara mengoptimalkan waktu anak dengan manajemen waktu di masa normal baru yaitu dengan membuat jadwal kegiatan harian, belajar bareng dan membuat prakarya. Adapun manfaat membuat jadwal kegiatan harian adalah sebagai berikut.
a. Membantu Manajemen Waktu
b. Meningkatkan Produktivitas
c. Mendorong Kreativitas

Adapun manfaat belajar bersama adalah sebagai berikut.

a. Membantu mendapatkan perspektif baru

b. Mengembangkan ketrampilan berpikir kritis

c. Mendorong cara belajar yang aktif d. Meningkatkan kemampuan berinteraksi dan bersosialisasi

e. Mengembangkan berbagai jenis soft skill

Adapun manfaat membuat prakarya adalah sebagai berikut.

a. Mengambangkan kreatifitas

b. Mengajar anak mengikuti intruksi

c. Membangun kepercayaan diri

\section{Participatory}

Pendamping membutuhkan stakeholder dalam pelaksanaan program kerja, diantaranya adalah perangkat desa, wali murid atau orang tua anak, dan anak-anak yang belajar di sekolah dan di rumah menggunakan sistem daring dan luring.

Berdasarkan hasil wawancara pendamping mendapatkan hasil sebagai berikut.

a. Mengatur waktu dengan teratur

Anak-anak belum mengatur waktu dengan baik sebelum adanya program pendampingan. Setelah adanya pendampingan, anak-anak dapat mengatur waktunya dengan baik karena ada pembuatan jadwal kegiatan harian, belajar bersama, dan pembuatan prakarya di akhir minggu yang dapat membuat anak-anak lebih kreatif dan produktif.

b. Menyelesaikan tugas tepat waktu

Anak-anak tidak memiliki jadwal rutin untuk belajar sebelum adanya program pendampingan, sehingga anak-anak hanya belajar ketika ada tugas saja dan tidak tepat waktu. Namun setelah adanya program belajar bersama, anak-anak berhasil 
menyelesaikan tugas tepat waktu.

c. Merencanakan jadwal dengan baik

Anak-anak merencanakan jadwal dengan

baik setelah adanya program pembuatan jadwal kegiatan harian. Program ini benarbenar efektif dalam penyusunan jadwal belajar anak-anak.

d. Menggunakan waktu secara efektif dan efisien

Selain dengan adanya pembuatan jadwal kegiatan harian dan belajar bersama, program pendampingan lainnya adalah pembuatan prakarya. Program ini memanfaatkan waktu luang anak-anak, sehingga waktu luang tidak terbuang siasia. Hal yang diperoleh pada program pembuatan prakarya selain untuk mengisi waktu luang anak, juga untuk menguji anak agar selalu kreatif dan produktif.

Hasil pendampingan diatas selaras dengan penelitian Hidayatullah tentang Pendampingan Pendidikan Anak di Kelurahan Genteng, Surabaya. Hasil dari penelitian tersebut yaitu permasalahan anak merupakan sebuah fenomena serius yang terjadi akhir-akhir ini. Kelalaian orang tua dalam memberikan perhatian dan kontrol terhadap anak bisa menjerumuskan mereka kedalam berbagai permasalahan. Pendidikan yang selama ini ada belum bisa menumbuhkan kesadaran anak untuk aktif serta dalam kegiatan-kegiatan sosial dan organisasi kepemudaan. Anak-anak lebih senang bermain game online dengan gadget. Waktu luang yang cukup banyak, seharusnya memberikan peluang bagi mereka untuk membangun karakter, dengan asumsi mendapatkan dukungan dan arahan dari orang tua. Seperti di kelurahan genteng Surabaya. Potensi yang ada belum bisa dimanfaatkan dengan baik. Adanya Taman Belajar yang selama ini dilaksanakan di balai RW kurang mendapatkan perhatian dari berbagai pihak. Adanya karang taruna, merupakan potensi yang sangat bagus. Pengabdian yang dilakukan dalam konteks ini yaitu memberikan parenting kepada orang tua dan anak, menghidupkan dan memberikan perbaikan pengelolaan Taman Belajar, dan kerjsama untuk menghidupkan kembali karang taruna sebagai entitas penting dalam pendidikan di masyarakat. Dengan terlaksananya program pengabdian ini, permasalahan pendidikan anak menjadi lebih baik, dan masayarakat menjadi peka terhadap masalah anak dan pendidikan.

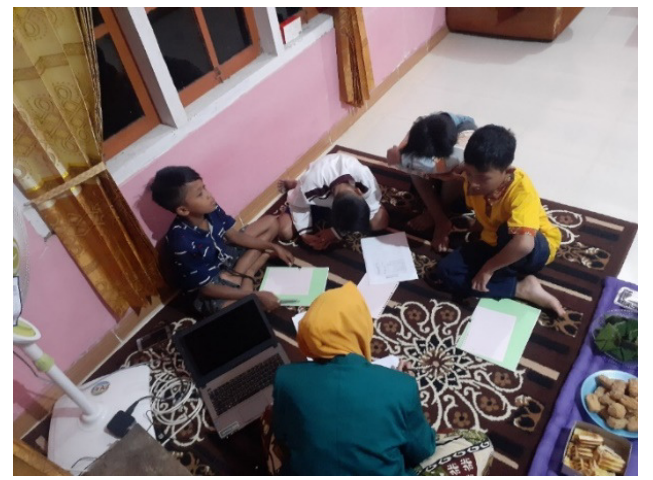

Gambar 1. Membuat jadwal kegiatan harian

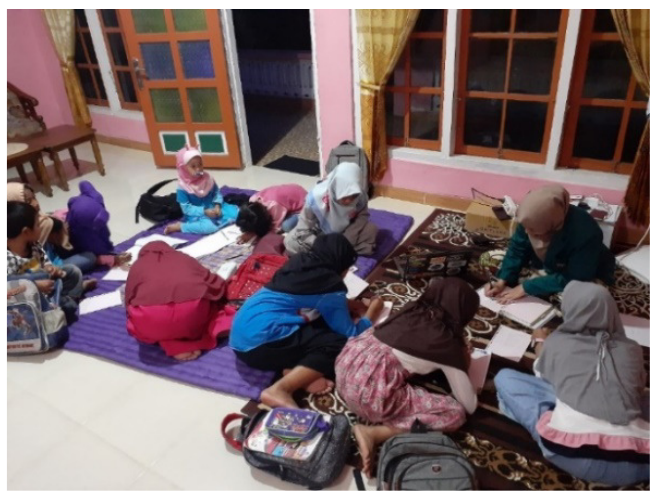

Gambar 2. Belajar bersama 


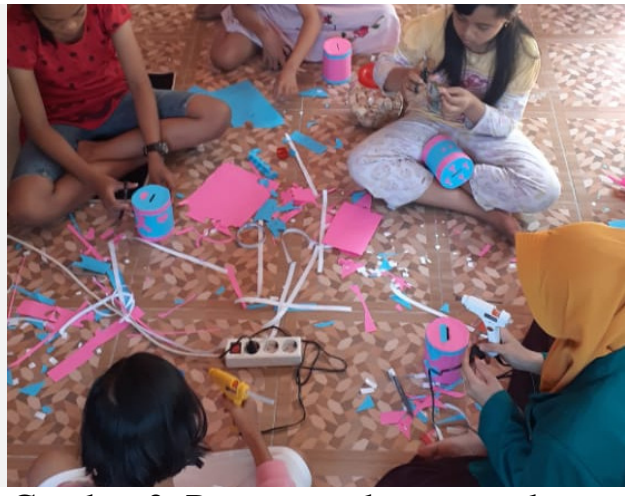

Gambar 3. Proses pembuatan prakarya (celengan)

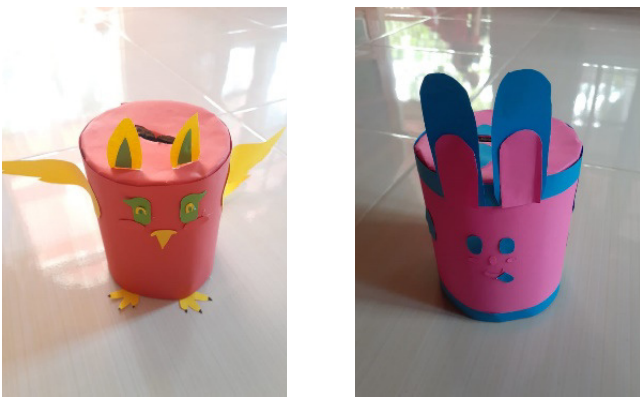

Gambar 4. Hasil karya anak-anak

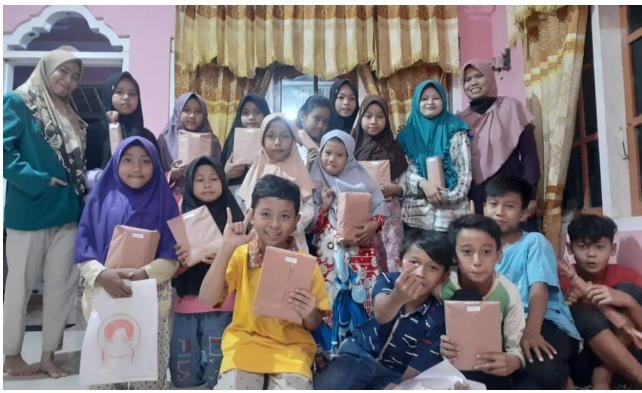

Gambar 5. Pemberian apresiasi

KESIMPULAN

Berdasarkan hasil dan pembahasan dalam pendampingan ini, diperoleh kesimpulan bahwa cara untuk mengoptimalkan waktu anak diantaranya dengan membuat jadwal kegiatan harian, belajar bersama, dan membuat prakarya di akhir minggu. Pendampingan ini dapat memberikan manfaat kepada anak-anak karena dengan adanya pembuatan jadwal kegiatan harian dapat membuat anak dapat mengatur waktu dengan efektif dan efisien, selain itu juga bisa membuat anak-anak lebih kreatif dan produktif karena adanya pembuatan prakarya. Pendampingan manajemen waktu anak memang sangat diperlukan di masa normal baru untuk mengoptimalkan waktu anak agar tidak ada waktu yang terbuang sia-sia.

\section{SARAN}

Hendaknya orang tua selalu dapat mendampingi anaknya dalam pelaksanaan jadwal kerja sehingga mereka akan mengerti bagaimana dengan manajemen waktu kegiatan anak akan mengerti bahwa waktu itu bukan untuk dibuang tapi dimanfaatkan dengan sebaik-baiknya.

\section{UCAPAN TERIMA KASIH}

Ucapan terimakasih disampaikan kepada LP3M STAI Al-Husain Magelang Dosen Pembimbing serta teman seperjuangan yang telah memfasilitasi dan mendukung secara penuh terhadap kegiatan pengabdian kepada masyarakat sehingga dapat berjalan dengan baik dan lancar sesuai dengan yang diharapkan.

Terimakasih juga disampaikan warga Desa Dasekan yang telah berpartisipasi secara aktif dalam kegiatan pengabdian kepada masyarakat ini.

\section{REFERENSI}

[1] Purwanto, Agus, Rudy Pramono, Masduki Asbari, Priyono Budi Santoso, Laksmi Mayesti Wijayanti, Chi Hyun Choi, and Ratna Setyowati Putri. 2020. Studi Eksploratif Dampak Pandemi COVID-19 Terhadap Proses Pembelajaran Online Di Sekolah Dasar. EduPsyCouns: Journal of Education, Psychology and Counseling 2 (1): 1-12.

[2] Santika, I Wayan Eka. 2020. Pendidikan Karakter Pada Pembelajaran Daring. Indonesian Values and Character Education Journal 3 (1): 8-19. 
[3] Situmorang, Sudirman. 2018. Peningkatan Daya Layan Sekolah Dan Pembelajaran Dengan Layanan Google. Jurnal Global Edukasi I (6): 663-72

[4] Sari, Indra Kartika. 2019. Pengaruh Manajemen Waktu Belajar Peserta Didik Kelas 5 Sdn Salatiga 05 Terhadap Nilai Raport. JPPGuseda I Jurnal Pendidikan \& Pengajaran Guru Sekolah Dasar 2 (2): 53-56.

[5] Wati, Mardeka, Nailul Himmi, Program Studi, Pendidikan Matematika, Fakultas Keguruan, Universitas Riau Kepulauan, and Kepulauan Riau. 2018. Hubungan Manajemen Waktu Belajar dan Peran Serta Orangtua Terhadap Prestasi Belajar Matematika Siswa Kelas XI IPA SMAN 5 Batam. Jurnal Dimensi 7 (3): 572-81.

[6] Junaidi, Ratih Kumala Ahmad. 2020.
Strategi Bisnis Dan Pemanfaatan Kebijakan Pajak Di Masa Pandemi COVID-19 Dan Era New Normal (Studi Kasus Pelaku UMKM Marketplace). Prosiding Seminar Stiami 5 (2): 55

[6] Sudrajat, Dadang, and Mohammad Ikbal Moha. 2019. Ragam Penelitian Kualitatif

[8] Aula Izatul, Muhammad Imam Khaudli, and Ribut Suprapto. 2018. Pemberdayaan Ekonomi Masyarakat Melalui Pemasaran Wisata Kuliner Jajanan Tradisoional Di Desa Cantuk Kabupaten Banyuwangi. ENGAGEMNT; Jurnal Pengabdian Kepada Masyarakat 2 (2): 168-75.

[9] Hidayatullah, Achmad. 2017. Pendampingan Pendidikan Anak Di Kelurahan Genteng Surabaya. Jurnal Pengabdian Kepada Masyarakat 1 (1): 45-51. 